\title{
EXPRESSING POLITICAL AND RELIGIOUS IDENTITY \\ Religion-Science Relations in Indonesian Muslim Thinkers 1970-2014
}

\section{Media Zainul Bahri}

State Islamic University (UIN) Syarif Hidayatullah Jakarta, Indonesia email:zainul.babri@uinjk.t.ac.id

\section{Abstract}

An attractive phenomenon of Indonesian Islam in 1990s era up to the recent time is an emergence of thought battle within Muslim scholars concerning religon and science. From the struggle, various terms have arisen such as: Islamization of knowledge/science, scientification of Islam, objectification of Islam, compatibility, ayatization or ayatisasi (from Arabic āya [verse, sign] i.e. to find the Qur'anic āya for every single knowledge/ science finding), integration, integration-interconnection, and so forth. According to the typology of Ian Barbour, instead of conflict and independence, religion-science relations in Indonesian Islam are always in the position of integration and dialogue. However, this article focuses on how the discourse of religion-science relations is conducted to express Islamic identity and political become more salient and stronger, particularly within Indonesian urban Muslims. Since the pioneers in 1970s to1980s such as Rasjidi, Moenawar Chalil, Buya Hamka and Syekh Kadirun Yabya, then more academic discourse such as the figures of Hidajat Nataatmaja, Kuntowijoyo, Mulyadhi Kartanegara and Amin Abdullah, to very popular writers of ayatisasi, Islamization of science has--at least three main agendas: the politics to strengthening Muslim identities, the spirit against secularist-Western, and apologetic attitudes as part of the theological campaign. This popular phenomenon shows that Islam is not merely regarded as 'a perfect religion' in terms of ethics, ritual as well as spiritual, but also it 
is kind of Islamic revival', i.e. a politically meaningful term, 'revival of the ummah in all its aspects'.

[Salah satu fenomena menarik islam Indonesia tabun 1990 an bingga sekarang adalah perdebatan pendapat diantara ilmuwan muslim terkait bubungan agama dan sains. Dari perdebatan tersebut setidaknya memunculkan istilab seperti islamisasi pengetabuan atau ilmu, ilmuisasi islam, obyektifikasi islam, keserasian, ayatisasi, integrasi, integrasi - interkoneksi, dan lainnya. Berdasarkan tipologi dari Ian Barbour, alih-alih konflik dan independensi, bubungan agama dan sains di muslim Indonesia lebih tepat berada diposisi integrasi dan dialog. Dalam artikel ini fokus tertuju pada bagaimana wacana bubungan agama dan sains sebagai ekspresi identitas politik dan keislaman, khususnya pada muslim perkotaan. Sejak 1970-1980an mulai dikenal nama-nama seperti Rasjidi, Moenawar Chalil, Buya Hamka dan Kadirun Yahya bingga nama - nama yang lebih akademis seperti Hidajat Nataatmaja, Kuntowijoyo, Mulyadhi Kartanegara dan Amin Abdullah. Setidaknya ada tiga agenda dari gerakan ini yaitu politike penguatan identitas keislaman, semangat melawan sekulerisasi barat dan sikap defensif yang merupakan bagian dari dakwah. Singkatnya, fenomena ini menunjukkan bahwa islam tidak hanya sebagai agama yang sempurna secara etis, tapi juga ini bagian dari kebangkitan islam seperti dalam istilah politiknya, kebangkitan islam di segala aspeknya.]

Keywords: Islam and science, Islamic identity, Secularist-Western, Postcolonial mentality

\section{A. Introduction}

An attractive phenomenon of Indonesian Islam in 1990s era to the recent time is an emergence of thought battle within Muslim scholars concerning religon and science. From the struggle, various terms have arisen such as: Islamization of knowledge/science, scientification of Islam, objectification of Islam, compatibility, ayatization or ayatisasi (from Arabic àya [verse, sign] i.e. to find the Qur'ānic āya for every single knowledge/science finding), knowledge/science integration, integrationinterconnection, theoanthropocentrist-integralist and so forth. Such phenomenon indicates some important common views. First, instead of conflict and independence, religion-science relations in Islam are always 
in the position of integration and dialogue, according to the typology of Ian Barbour. ${ }^{1}$ Second, the phenomenon shows that Islam is compatible with modernity, since science and modernity are considered identical. Third, no doubt according to Muslims that Islam as revealed religion has adjusted all the details of life, including scientific cues.

However, this article will not discuss those general views. Instead of, I shall focus on how the discourse of religion-science relations made Islamic identity and political more salient and stronger, particularly within Indonesian urban Muslim communities.

\section{B. What is Political and Religious Identity?}

What I mean by 'identity' in this article consists of two meanings. First, religious and cultural identity. Federico Magdalena illustrates it clearly:

Identity is the sense of being, or of becoming, a badge that distinguishes one from others. Descartes' famous line "I think therefore I am" is a crucial index of the novel stress on identity. This sense of self is validated by membership in a group, or affiliation in something intangible like culture or religion. ${ }^{2}$

Individual, cultural, and religious identities need to be acknowledged or need to find that he/she or they don't only 'exist' but also are different from others. The Islam identity was first expressed in the sentence: 'I am Muslim before everything'. The expression of each Muslim individual is then merged into one concept of ummah (Muslim community). The individual identity is now gathered in one great communal identity, the ummah: 'we are the Muslim ummah'. The strengthening of this Islamic identity is followed by a spirit against the hegemony of a positivist Western science. Here one can see the spirit of resistance. According to Bagir, the resistance must be seen as a response to the introduction of modern science, initially during the time of colonization of Muslim lands by western powers. For Bagir, the phenomenon of Islamization

1 Barbour utilizes four types concerning the religion-science relation: (1) Conflict, (2) Independence, (3) Dialogue, and (4) Integration. See Ian G. Barbour, When Science meets Religion: Enemies, Strangers, or Partners? (New York: Harper Collins, 2000).

2 Federico V. Magdalena, "Islam and the Politics of Identity", Center for Philippine Studies, http://www.hawaii.edu/cps/identity.html, accessed 6 Jun 2016. 
of science must be seen that Indonesian Islam is part of the Muslim world. In the Muslim world, discussions about Islam and science had existed for a long time, but it was not systematic, and mostly spoke about the history of science in Islam, especially in the period of the so-called 'Golden Age', and much of it was apologetic. ${ }^{3}$ At the same time, Muslims feel as Western-dominated communities, not only physically, but also culturally and in ways of thinking. In the Indonesian context, during the 1980s and 1990s many of the world's Islamic books are translated into Indonesian. One of the interesting topics to discuss was the critique of Western science and the need to build a science based on some Islamic epistemology. This topic was also popular among Muslim scholars in the US and Europe. ${ }^{4}$ This spirit was appreciated by Indonesian Muslim. By general, we can see this phenomenon as a resistance to Western domination.

Secondly, the cultural identity of religion in turn becomes 'Islamic political identity'. This identity, if following Bassam Tibi, is also called Islamism. Tibi explains:

Islamism is about political order, not faith. Nonetheless, Islamism is not merely politics but 'religionized politics'. In the case of Islamism, the 'religionization of politics' means the promotion of a political order that is believed to emanate from the will of God and is not based on popular sovereignty. Islam itself does not do this. ${ }^{5}$

Tibi gives, at least, six characteristics of Islamism: (1) Islamic political order, (2) anti-Semitism, (3) anti-democracy, (4) sharia formalization, (5) Islam authenticity and purity; and (6) totalitarianism. According to Tibi, Islamism is completely different from Islam. Islamism is a new construction of "religion and state" that ignores 'faith, spirituality, inclusive ethical values, and enlightened reason'. Islamism is a political institutionalization with its interests and agendas by wearing 'Islamic clothes'.

3 Zainal Abidin Bagir, "Expanding Science and Religion in the Pluralistic Landscape of Today's World", Science and Religion in a Globalizing World (Star Island, New Hampshire, 2014), https:/ /irasconference.files.wordpress.com/2014/08/august4-presentation-draft-iras-august-2014-zain-bagir-2.pdf, accessed 10 May 2016.

4 Ibid.

${ }^{5}$ Bassam Tibi, Islamism and Islam (New Haven: Yale University Press, 2012), p. 1. 
The concept of umma in Islamism means citizenship that exists in the Islamic system (al-nizām al-Islämi). This Islamism, in its extreme practice, manifests itself in the form of organizations and groups shouting jihad, in the sense of war against anyone who disagrees with them, as we have seen in many places. The Indonesian initiators of Islamization of science are, of course, not in the Tibi's "hard Islamism" category, but that among them are members or supporters of Islamic political parties who want the Islamic system; or some support the formalization of the Sharia; or some others actively preach "pure, authentic, and käffah" Islam as a way of life, then their formulations on the Islamization of science can be read as 'soft-Islamism'.

\section{Recognizing the pioneers: Moenawar Cholil, Rasjidi, Kadirun Yahya, and Buya Hamka}

Historically, since its publication in November 1859, Darwin's work, The Origin of Species, elicited much attention and controversy, especially among churches. According to Jon Roberts, Christian thinkers in Great Britain and the United States who interested in religion-science relations in the period prior to 1875 commonly denounced The Origin of Species as an assault on 'the fundamental principles both of natural and revealed religion'. ${ }^{6}$ However, by 1920s, when the fundamentalist Christian in the United States and Europe denied the theory of evolution, especially efforts to outlaw the teaching of human evolution in the public schools of America in the early 1920s, the theory of evolution had become the most theologically controversial scientific hypothesis since the time of Galileo. ${ }^{7}$ The Church (and Muslim scholars as well) comprehended the theory stating that species of creatures have gradually changed. This gradual change of all species, flora and fauna, exists within mecanical law which is the so-called 'natural selection'. It is this law that elucidates a phenomenon of creatures evolution in the scientific term, apart from religious dogma. Another thesis of the evolution theory is that human ancestor is an ape. Of course, this theory contravenes to the doctrine of

${ }^{6}$ Jon H. Roberts, "Religious Reactions to Darwin", in The Cambridge Companion to Science and Religion, ed. by Peter Harrison (Cambridge: Cambridge University Press, 2010), p. 81.

7 Ibid., p. 80. 
creation in Christian and Islam stating that Adam and Eve are created by God. Surprisingly, Buya Hamka (Haji Abdul Malik Karim Amrullah), an outstanding figure of Muhammadiyah and influencial religious scholar of Indonesia, in his Tafsir Al-Azhar volume 1, advances an interesting commentary about the relation between the Prophet Adam as the first human being, the relation of the Qur'ānic verses of creation, khiläfa (caliph), and Darwin's theory. ${ }^{8}$ Later on, Mulyadhi Kartanegara, a professor of Islamic philosophy at UIN Jakarta, also comments in adequate manner about Islamic philosophical view and the Qur'ān vis a vis Darwin's evolution theory. ${ }^{9}$

Indeed, struggle of religion-science already began since 1970s in various themes, e.g. the relation of Isrä'-Miraj and science. Kyai Haji Moenawar Chalil's work, Peristiwa Isra dan Miraj (An Episode of Isrā'Mi'rāj) ${ }^{10}$, and Professor Syekh Kadirun Yahya's book entitled, Isra Mi'raj Rasulullah Saw: Ditinjau dari Sudut Ilmu Fisika-Eksakta (The Prophet's Isrā'-Mi'rāj: Viewed from Physical Science ${ }^{11}$ are two representative and popular books at their contemporary, in which they concerned that Islam, represented by the occurrence of Isrä'-Miräjj, is appropriate with theories of physics and astronomy, even they went beyond the science that just recently found. Soon after, Professor Thomas Djamaluddin, a chief at Lembaga Penerbangan dan Antariksa Nasional/LAPAN (National Institute of Flight and Outerspace), also published a fascinating article entitled "Isra Miraj: Inspirasi Mengintegrasikan Sains dalam Aqidah dan Ibadab" (Isrä'-Mirräj: An Inspiration to Integrate Science within Faith and Piety" ${ }^{12}$ Djamaluddin is an astronomist, and figure of LAPAN, who

${ }^{8}$ Hamka, Tafsir al-Azhar, vol. 1 (Jakarta: Pustaka Panjimas, 1983), pp. 159-61.

9 R. Mulyadhi Kartanegara, Menembus Batas Waktu: Panorama Filsafat Islam (Bandung: Mizan, 2002), pp. 144-63. It is important to note that prior to Indonesian Muslims who intensively discussed on Islam and evolution (especially in 1990s), a Turkey apologist Muslim, Harun Yahya, published his several books on theory of evolution (translated into Indonesian) which was warmly welcome by Indonesian Muslims.

10 Moenawar Chalil, Peristiwa Israa' dan Mi'radj (Djakarta: Bulan Bintang, 1960).

11 Kadirun Yahya, Isra Miraj Rasulullah Saw: Ditinjau dari Sudut Ilmu Fisika-Eksakta (Medan: Lembaga Ilmiah Metafisika Tasauf Islam, 1985).

12 Thomas Djamaluddin, 'Isra' Mi'raj: Inspirasi Mengintegrasikan Sains dalam Aqidah dan Ibadah", dakwatuna.com (2011), http://www.dakwatuna. com/2011/06/27/12964/isra-miraj-inspirasi-mengintegrasikan-sains-dalam-aqidah- 
actively proposed a solusion of hisäb (calculation) and ru'ya (sight) to decide the date of fasting month (Ramadān), $\bar{T} d$ al-Fitrand ' $\bar{I} d a l-A d h \bar{a}$, in which this has annually become polemic in between the government, NU (Nahdlatul Ulama), Muhammadiyah, an other Islamic non-government organizations.

Another popular book in the Archipelago is La Bible le Coran et la Science ${ }^{13}$ by Maurice Bucaille, and translated by Professor H.M. Rasjidi with the title Bibel, Quran dan Sains Modern. ${ }^{14}$ Rasjidi is an alumnus of Universitas Sorbonne, Paris, and an Indonesia Muslim scholar who is fond of Islamism, and he was the Minister of Religious Affairs in the era of President Soekarno. This book was really popular in the last 1970s up to 1980s, since its substance 'satisfied' Indonesian Muslims, in which it explained many scientific fallacies inside the Christian Bible and, on the contrary, the suitable scientific theory with the Qur'ān. This spirit is actually showed by Rasjidi in order Indonesian Muslim could "find the truly truth and the way of life". ${ }^{15}$ The serious debate in the Indonesian Muslim circles on relation of science and the Quran, as an impact of Bucaille's book, is hardly depatched from Rasjidi's role as a Muslim scholar who translated and popularized the book.

I want to link the four pioneers to the political context of Muslims during the formation period of the nation-state of Indonesia. Moenawar Cholil and Buya Hamka, for example, had been active in the Masyumi

dan-ibadah/.

13 Maurice Bucaille is a French docter who mastered Arabic languageto understand the Qur'ān. His book, La Bible le Coran is his first work becoming the bestseller in all Muslim world. See Maurice Bucaille, La Bible, le Coran et la science: les Écritures saintes examinées à la lumière des connaissances modernes (Paris: Pocket, 1976).

14 H.M. Rasyidi, "Pengantar", in Bibel, Quran, dan Sains Modern, trans. by H.M. Rasyidi (Jakarta: Bulan Bintang, 1978).

${ }^{15}$ See Rasjidi's "Introduction” in Maurice Bucaille, Bibel, Quran dan Sains Modern. Ibid., pp. 9-10. In 1984, Bucaille also publicated another book, What is the Origin of Man? The Answers of Science and the Holy Scriptures, see Maurice Bucaille, What is the origin of man?: the answers of science and the Holy Scriptures (Paris: Seghers, 1984). The book was then published by Mizan publisher with the title Asal Usul Manusia Menurut Bibel, Al-Quran dan Sains, see Maurice Bucaille, Asal-Usul Manusia Menurut Bibel, Al-Quran, Sains, trans. by Rahmani Astuti (Bandung: Mizan, 1986). Referring to the Holy Scripture, Bucaille refuses the theory of evolution. This book was popular particularly in the student circle and activists at campuses science-based, therefore the book was reprinted seven times. 
party, a party initiated by Islamic figures such as Hasyim Asy'ari and Wahid Hasyim from NU, Ki Bagus Hadikusumo and Kasman Singodimejo from Muhammadiyah. This party became a leading party when led by Muhammad Natsir (1908-1993). Masyumi was founded in November 1945 and dissolved by President Sukarno in 1960 because the party leaders were considered "participating in rebellion by joining the Revolutionary Government of the Republic of Indonesia (Pemerintaban Revolusioner Republik Indonesia (PRRI)". ${ }^{16}$ Remy Madinier notes, Cholil was one of the most influential clerics (ulama) in the ranks of Masyumi leaders, while Buya Hamka had been an elected representatives of Masyumi in the DPR in the late 1950s, became central Muhammadiyah leader in 1931, and became chairman of the first MUI in 1975. According to Madinier, the realization of Islamic society together with the establishment of Sharia State was a raison d'être of Masyumi. Despite the many disagreements within the party, the Masjumi leaders never subsided fighting for those ideals, namely Islamic society based on Islamic Sharia. ${ }^{17}$ This is what Bassam Tibi called as 'Islamism'.

The three figures who then initiated the Masjumi, namely Hashim, Hadikusumo, and Singodimejo once proposed the Jakarta Charter as a political representation of Muslims, but was failed because of strong opposition by Christian figures in Eastern Indonesia. However, the Islamic figures, until the formation of Masyumi, never subsided to do "Islamization". The nature of Cholil and Hamka's Islamism was also very clear. Cholil wrote many works that campaigned for his ideology of Islamism, one of the typical examples is Kembali Kepada al-Quran dan $S_{\text {Sunna }}{ }^{18}$. In another article titled Ulil Amri ${ }^{19}$, Cholil strongly criticized the title of ulil amri given by NU to Sukarno. According to Cholil, the title award to Sukarno was a deviation from the teachings of the Quran. For Cholil, the meaning of ulil amri in sura al-Nisa was not as understood by

16 Remy Madinier, Partai Masjumi: Antara Godaan Demokrasi \& Islam Integral (Bandung: Noura Book Publising, 2013), p. 265.

17 Ibid., p. 370.

18 Moenawar Chalil, Kembali kepada al-Qur'an dan as-sunnah: Suatu muqaddamah bagi bimpunan hadist - hadist pilihan (Jakarta: Bulan Bintang, 1977).

19 Moenawar Chalil, Ulil Amri (Sala: Ramadhani, 1984). 
the scholars of $\mathrm{NU}^{20}$

Like Cholil, Hamka was also very strong with the spirit of Islamism. In Deliar Noer's study, when comparing Islam with Pancasila, then for Hamka, Islam was superior to Pancasila, even to any understanding in this world. Hamka doubted if Pancasila was considered as a philosophy and lifestyle of indigenous Indonesians. For Hamka, Islam is the original foundation of Indonesia people, not Pancasila. According to Hamka, the Muslims spirit since the war against the invaders to independence, its driving force was Islam. Therefore, Hamka rejected the view that Pancasila was the 1945 proclamation spirit. "It is very far from the truth and, in abusive word, is a lie", said Hamka. For Hamka, Pancasila was known only to a few people, while most of Indonesia's population embraces the original foundation of Islam. It was clear to Hamka "Pancasila has no historical basis in Indonesia”. But according further to Deliar Noer, when Hamka became the chairman of MUI in 1975, Hamka looked a bit "soft". When discussing Pancasila, Hamka concluded that Pancasila was not against Islam. All the precepts were not separate from the spirit of God. According to Noer, Hamka must now be careful. If he had been hard and rebellious, now he tried to stand between the Muslims and the government, and tried to bring the two closer together. ${ }^{21}$

The soul of Islamism in Hamka and Cholil never faded. In the often-heated Christian and Islam relations context, Cholil and Hamka were two hard-earned figures. In the colonial era for example, Cholil as a Muhammadiyah leader in Semarang, had strongly protested the unfair Dutch colonial policy of subsidizing religious followers. According to Cholil, as quoted by Ropi, in 1936, subsidies received by Protestants amounted to f. 686,100, Catholics received f. 286,500, while Muslims received only f. 7,500. The following year, Protestants and Catholics received a significant increase of f. 844,000 and f. 335,700, while Muslims received only f. $7,600 .^{22}$

20 Madinier, Partai Masjumi: Antara Godaan Demokrasi \& Islam Integral, p. 19.

21 Deliar Noer, Membincangkan Tokoh-Tokoh Bangsa (Bandung: Mizan, 2001), pp. 76-9.

${ }^{22}$ Ismatu Ropi, Fragile Relation: Muslims and Christians in Modern Indonesia (Jakarta: Logos Wacana Ilmu, 2000), p. 29; Ismatu Ropi, Religion and Regulation in Indonesia (Singapore: Palgrave Macmillan, 2017), p. 53. 
Similarly, in the late 1960s, when the rumors circulated about the activity of Christianization and the emergence of rumors that Protestant missionaries had converted 2 million Muslims, the Muslim figures at the time responded very strongly. On November 30, 1967, when the government held a forum of national friendship among religious leaders, Muhammad Natsir, Rasjidi, Fakih Usman, Prawoto Mangkusasmito, and Hamka representing Muslims demanded the government to issue a strict rule that prohibits the religion broadcasting to the other religions' followers. But this demand was rejected by Christian leaders on that religious broadcasting was a human right. ${ }^{23}$ However, Hamka and his friends never gave up. They then lobbied the minister of religious affairs, Alamsjah Ratu Perwiranegara (a minister in 1978-1983). Alamsjah was known to be close to Islamic groups. Although he did not like radical Islam, but as a general with a santri background, he did not want the political power of Islam to be totally paralyzed as wanted by Ali Murtopo's group. Therefore, on August 1, 1978 Alamsjah issued the Regulation of Minister of Religious Affairs no. 70/1978 which contains restrictions on religious broadcasting of any kind to people who have embraced a religion. Of course, this regulation's intent was directed to Christian groups. This minister of religion's regulation, which reinforced the previous President's instruction on the religious broadcasting ethical code, was just welcomed by Islamic groups, including Hamka who was then the chairman of MUI. According to Hamka, as quoted by Ropi, this regulation on (Christian) religious propagation was important to limit radical tendencies within the Islamic community. He reasoned that mission carried out through door-to-door visits could lead to fatal results because "for a fanatical Muslim, it is permitted to kill such a missionary", said Hamka. ${ }^{24}$

Like Cholil and Hamka, Rasjidi was also a pure Islamist. It's just that the main difference with the two names above is that Rasjidi was a diplomat who several times became the Ambassador of Indonesia abroad, the first Indonesian to earn the title of "docteur" from a prestigious university in Paris, and became the Republic of Indonesia's first minister

23 Madinier, Partai Masjumi: Antara Godaan Demokrasi \& Islam Integral, p. 402.

24 Jan S. Aritonang, Sejarah Perjumpaan Kristen dan Islam di Indonesia (Jakarta: BPK Gunung Mulia, 2005), pp. 430-1; Ropi, Religion and Regulation in Indonesia, pp. 168-9. 
of religious affairs in 1946. This was what made Rasjidi look very special. Rasjidi came from the "abangan Muslim (red Muslim)" family; Muslims who do not practice Sharia. But since lecturing in Cairo in 1931 to the end of his life, Rasjidi was known as 'a guardian of faith.' Azra calls him an orthodox who had abandoned his ancestral "Javanese Islam" tradition fully. Even Rasjidi wrote a book entitled "Islam dan Kebatinan" which refuted the "Aliran Kepercayaan" or "Javanese Mysticism (Kebatinan Jawa)" and considered it "not Islam." ${ }^{25}$ In the midst of the Christianization of the late 1960s as mentioned above, Rasjidi also appeared in front of a strong reaction against Christians. Even Rasjidi spent a great deal of energy writing some papers as his rejection of the Christianization effort in Indonesia, among others, Mengapa Saya Tetap Memeluk Islam, Sikap Ummat Islam Terhadap Ekspansi Kristen, and Kasus RUU Perkawinan dalam Hubungan Islam dan Kristen. When speaking at an interfaith seminar in Tokyo in 1968, Rasjidi also made a paper that strongly criticized Christian missionary efforts in Indonesia and referred to them as "uncivilized ways". ${ }^{26}$

The Islam puritanism soul of Rasjidi re-emerged when the ideas wave of Islamic renewal was raised by Ahmad Wahib, Nurcholish Madjid, and Harun Nasution in the mid-1970s. Rasjidi wrote two special works and one short article to criticize theirs ideas which were considered to deviate from the true teachings of Islam. Against Cak Nur's idea of secularization and renewal, Rasjidi concluded that Cak Nur's thoughts were "dangerous to the Indonesian Muslim community". ${ }^{27}$ On the "rational Islam" project of Harun Nasution, Rasjidi also concluded that Nasution's ideas threaten Islam and Muslims in Indonesia. ${ }^{28}$ Against Wahib's journal, which later became Pergolakan Pemikiran Islam, Rasjidi commented that Wahib was a bright young man, but for lack of guidance he became "digressing in his error." According to Rasjidi, it was a tragedy, when secular Westerners had

25 Azyumardi Azra, "HM Rasjidi: Pembentukan Kementerian Agama dalam Revolusi", in Menteri-Menteri Agama RI: Biografi Sosial-Politik, ed. by Azyumardi Azra and Saiful Umam (Jakarta: Badan Litbang Agama, Departemen Agama \& PPIM-IAIN, 1998), p. 15.

26 Ibid., p. 24.

${ }^{27}$ H.M. Rasjidi, Koreksi terhadap Drs. Nurcholis Madjid tentang Sekularisasi (Jakarta: Bulan Bintang, 1972), p. 85.

28 M. Rasjidi, Koreksi terhadap Dr. Harun Nasution tentang "Islam ditinjau dari berbagai aspeknya” (Jakarta: Bulan Bintang, 1977), p. 107. 
returned to religion, and while he was translating Maurice Bucaille's work on the greatness of the Quran in science, Indonesians were even treated to Wahib's journal. ${ }^{29}$ For his solid attitude of defending "pure Islam" came the question: as a European graduate, why Rasjidi did not inherit a liberal Western intellectual tradition? Or the Javanese tradition, as his ancestral culture, about religious harmony and syncretism? According to Azra, the answer to that question seems indispensable from the intellectual and religious environment that Rasjidi experienced while studying in Cairo. Rasjidi felt comfortable with understanding of reformism or "neosalafism" as campaigned by Afghani, Abduh, and Ridha. The hallmark of neo-salafism was to return to the Quran, sabih hadith, or to "pure Islam" as practiced by the salaf, and to reject heresy and superstition. Rasyidi while in Cairo was also close friends with Sayyid Qutb, the main figure of reformism. Therefore, according to Azra, Rasjidi together with Cholil and Hamka deserved to be called an orthodox Muslim, a revivalist or a reformist, and even a "fundamentalist". Being called "fundamentalist", Azra said, Rasjidi did not mind, even honored with the nickname, as he indeed devoted himself to preserving the fundamentals of Islamic faith. ${ }^{30}$ That's what Rasjidi embraced until his death.

The broad picture above I explain deliberately is nothing but to show that the political activity of Islamic identity becomes the spirit, attitude, and practice of the pioneers of religious and science relations. Their Islamism becomes the spirit that moves all their thoughts and works about Islam. However, it must also be understood that the identity politics, communal politics, or religious politics battle in a newly independent nation at that time and seeking a nation-state form, is normal. All ethnic and religious groups are indeed offering their respective identity forms, and so it is possible to contest and conflict with each other.

\section{Ayatisasi and the Spirit against Secularist-Western}

After the four figures above, then Hidajat Nataatmaja (19322009) emerges as another Muslim scholar who intensively discussing

29 Ahmad Wahib, Pergolakan Pemikiran Islam: Catatan Harian Ahmad Wabib, ed. by Djohan Effendi and Ismed Natsir (Jakarta: Lembaga Penelitian, Pendidikan dan Penerangan Ekonomi dan Sosial, 2003), pp. 372-3.

30 Azra, "HM Rasjidi: Pembentukan Kementerian Agama dalam Revolusi”, p. 26. 
religion-science relations. Hidayat is a bureaucrat and scientist and has no background in Islamic studies. In the context of Islamization of sciences he was quite popular around the Muslim middle class of Indonesia in the period 1980s to 1990s. Hidajat's works are about Islam and science crisis, some of them included the spirit against secularist-Western. One of his prominent book, Karsa Menegakean Jiwa Agama dalam Dunia Ilmiab: Versi Baru Ibya Ulumuddin (An Effort to Establish Religious Spirit within Scientific World: New Version of Ibyà Ulüm al-Dìn), critizises empirical and rational knowledge (which develop in the Western world and Indonesia) with the methaphysic perspective of Ibya a Uum al-Din written by al-Ghazālī. Hidajat wanted to fight a well-established positivist paradigm stating that Western science is universal and objectively suitable for all humanity. ${ }^{31}$ In fact, according to Hidajat that Western science is 'false and tricky'. ${ }^{32}$ Hidajat noted what he so-called 'devil's traces' (jejak Iblis $)^{33}$ for the paradigm stating that "science must be true, objective and universal'. This 'devil's traces', according to Hidajat, originate from a cult of rationalism and empiricism promoted by Western scientific traditions. ${ }^{34}$

To indicate that he was a scientist who apprehends the works of Western philosophy, Hidajat, within his works called many figures of science and philosophy such as Goedel-Weisskopf, Newton, Albert Einstein, Karl Popper, Thomas Kuhn, Fritjof Capra, Hideki Yukawa, Edward de Bono, Karl Marx, Sigmund Freud, Abraham Maslow, Plato, Aristoteles, Descartes, E.F. Schumacher, Immanuel Kant, Joan Robinson, Alfin Toffler, William Barret, Gunnar Myrdal etc. Again, for Hidajat, what the so-called rationalism and empiricism that have always been considered solid, are fragile and weak. On the contrary, according to Hidajat, Islam includes the rational, the empirical, and the metaphysical altogether. Using the metaphysical, through Sufism, will produce the scientific traditions which are solid and authentic. For him, the Quran is the source of science that inspires scientific findings. Why do Muslims blindly follow Western science and leave the Quran? All of the most

31 Hidajat Nataatmadja, Karsa Menegakekan Jiwa Agama dalam Dunia Ilmiah: Versi baru Ibya Ulumuddin (Bandung: IQRA, 1982), p. 29.

32 Ibid., pp. 25-8.

33 Ibid., p. 29.

34 Ibid., pp. 30-1. 
recent scientific discoveries have been described by the Quran. Hidayat regretted that the Western Scholars more understood the content of the Quran than the Muslims themselves. ${ }^{35}$ For Hidajat, religion and science are united. Both are inseparable. ${ }^{36}$ What is interesting about all of Hidajat's formulation of the Islamic-science relations is Hidajat's statement that the ultimate goal of his formulas is 'Islamic revival', ${ }^{37}$ i.e. a politically meaningful term, 'revival of the ummab in all its aspects'.

Accordingly, Mulyadhi Kartanegara is another example. Mulyadhi is well-known as UIN Jakarta's figure who formulates the Islamization of knowledge as well as the integration of knowledge. The spirit of Mulyadhi's writings is the resistance to a positivistic Western scientific model. According to him, Western secular science became a threat, and even attacking the main pillars of belief in God. Mulyadhi is restless on this matters and concerned that Western secular science models will undermine the religious education models which based on faith. In his work, Menembus Batas Waktu, Mulyadhi made a chapter to criticize the main scientific figures such Darwin, Marx, Freud, and Durkheim, whom inspired the emerge of modern and positivist Western sciences. ${ }^{38}$ However, the formulation of Mulyadhi's Islamization of science is more epistemological, so I put him in the academic category, as I will discuss later.

Ayatisasi or Ayatization is another issue concerning religion-science relation. Actually, ayatisasi is a part of what the so-called "Tafsir Ilmi". Ayatisasi means interpreting the Quran by using the findings of scientific research.$^{39}$ In other words, ayatisasi is to give Quranic verses upon science, social, and other knowledge, which are considered in accordance with the Quran. ${ }^{40}$ Perhaps, this is the most popular phenomenon in Indonesian Islam. It is the model that many Indonesian Muslim authors desire. Ioanes

35 Ibid., p. 23.
36 Ibid., p. 5.
37 Ibid., p. 12.
38 See Kartanegara, Menembus Batas Waktu, pp. 144-63.
39 Agus Purwanto, Nalar Ayat-Ayat Semesta: Menjadikan al-Qur'an Sebagai Basis Konstruksi Ilmu Pengetahuan (Bandung: Mizan, 2015), p. 5.

40 Edwin Syarif, "Islamisasi Ilmu di UIN Syarif Hidayatullah Jakarta", Ph.D. Dissertation (Jakarta: UIN Syarif Hidayatullah, 2011), p. 107. 
Rakhmat, an Indonesia Christian scholar, states cynically that ayatisasi is 'cocokologi' (cocok: suitable, match.) Cocokologi means to adjust by force the scripture texts with the modern science. Wherever the modern science moves, to such distance the holy scripture must be directed and forced as well to suit the modern science. ${ }^{41}$

Given very popular, there are lots of works (books and articles) which use model of ayatisasi since 1990s until 2014. I would like to categorize the models of ayatisasi into two important parts: first, softayatisasi (SA), and second is hard-ayatisasi (HA). First, Soft-ayatisasi is another term of what so called "compatibility." Some scholars on this model state that the Quran is not solely inspiring science development, but is also compatible with it. Some works on this including: Sains dan Teknologi Dalam Islam, Tinjauan Genetis dan Ekologis ${ }^{42}$ by Hasan Basri Jumin. Jumin is a scientist who earned MA and Ph.D in Biotechnology and Breeding at Kagoshima university of Japan; Science and Technology: Some Cases in Islamic Perspective ${ }^{43}$ by Subandi dan Hany Hanita Humanisa. Both Subandi and Humanisa are lecturers at UIN Bandung; and two remarkable Muslim scholars exploring this model are Nurcholish Madjid and Quraish Shihab.

According to Madjid, there are countless signals about science in the Quran. Madjid even testifies that one of the greatest discovery from Islamic umma is figure zero. Without number zero, math would not exist as seen now. ${ }^{44}$ While Shihab, as a mufassir of the Quran, sees a proportional relation and compatibility between the Quranic holiness and science. Shihab is convinced that there are scientific signals inside the Quran, or at least there are verses touching and tracing scientific truth which is still not discovered, nor recognized, by scientists. But Shihab warns about the fundamental different nature between science and the Quran. Science is always relative in manner. All scientific inventions are not eternal. Every science recognized in the past as 'established theory'

41 Ioanes Rakhmat, Beragama dalam Era Sains Modern (Jakarta: Pustaka Surya Daun, 2013), p. 76.

${ }^{42}$ Hasan Basri Jumin, Sains dan Teknologi dalam Islam tinjauan Genetis dan Ekologis (Jakarta: PT RajaGrafindo Persada, 2012).

43 M. Subandi and Hany Hanita Humanisa, Science and Technology Some Cases in Islamic Perspective (Bandung: Remaja Rosdakarya, 2011).

44 Nurcholish Madjid, "Metodologi dan Orientasi Studi Islam Masa Depan”, Khazanah, Jounal of Islamic Studies, vol. 1, no. 1 (2002), pp. 8-9. 
will perhaps be denied or cancelled by the newest scientific theory. On the other hand, the Quran is 'eternal' for it comes from the Most Eternal One. Since the Quran is not a science-book, Shihab says, then the best behavior is "not to justify neither to blame a scientific theory with the Quranic verses which truly do not deliberate those scientific problems in detail". ${ }^{45}$ It is just enough to say that some Quranic verses or the spirit of some verses are compatible with scientific discoveries.

Second, HA is to give Quranic verses upon science and knowledge per se. In other words, HA is more real than the compatibility. For this model, some Muslim authors (or Islamic organizations) convinced that many Quranic verses are not merely compatible, but even identical with some scientific discoveries. Although there are many writings on this subject, I would like to mention some important works, including Al-Islam dan Iptek (1997) is a book resulted by civitas academica at Universitas Muhammadiyah wholeover Indonesia. The book was tought in all universities of Muhammadiyah in Indonesia and of course this was supported by Pimpinan Pusat Muhamadiyah (Muhammadiyah Center Leadership); Islam dan Sains Modern ${ }^{46}$ by Ali Anwar Yusuf. Anwar is a lecturer at UIN Bandung; Menyibak Rahasia Sains Bumi dalam Al-Quran ${ }^{47}$ by Ir. Agus Haryo Sudarmojo. Sudarmojo is an engineer; Nalar Ayat-Ayat Semesta, Menjadikan Al-Quran Sebagai Basis Konstruksi Ilmu Pengetabuan ${ }^{48}$ by Agus Purwanto D.Sc. Purwanto is a scientist who earned MA and Ph.D in Physics at Hiroshima university of Japan. The Ministry of Indonesian Religious Affairs also published in 2012 three serial 'scientific tafsir': Penciptaan Jagat Raya dalam Perspektif al-Qur'an dan Sains (Buku I), Penciptaan Bumi dalam Perspektif al-Qur'an dan Sains (Buku II), and Penciptaan Manusia dalam Perspektif al-Qur'an dan Sains (Buku III). ${ }^{49}$ Interestingly, academic

45 M. Quraish Shihab, Membumikan Al-Quran (Bandung: Mizan, 2003), p. 49.

46 Ali Anwar Yusuf, Islam dan Sains Modern: Sentuban Islam terbadap berbagai disiplin ilmu (Bandung: Pustaka Setia, 2006).

${ }^{47}$ Ir Agus Haryo Sudarmojo, Menyibak Rahasia Sains Bumi Dalam Al-quran (Jakarta: Mizania, 2008).

48 Purwanto, Nalar Ayat-Ayat Semesta.

49 Lajnah Pentashihan Mushaf al-Qur'an Kementerian Agama, Penciptaan Jagat Raya dalam Perspektif Al-Qur'an dan Sains (Jakarta: Lajnah Pentashihan Musahaf alQur'an, Badan Litbang \& Diklat, Kementerian Agama RI, 2012). In 2017, the Ministry of Religious Affairs launched a highly prestigious of Tafsir Ilmi with 14 volumes titled 
community of Salman at ITB (Institut Teknologi Bandung) also published tafsir with ayatisasi model, Tafsir Salman: Tafsir Ilmiah atas Juг 'Amma (2013).

However, the most impressive and controversial figure in ayatisasi is Fahmi Basya. His book Matematika Islam: Sebuah Pendekatan Rasional untuk Yaqin $^{50}$ was published for the first time in 2004, and was reprinted 21 times in July 2014. He relates most math formula with the Quranic verses to show the convincing suitability between math and the Quran. ${ }^{51}$ This directly shows the miracle of the noble Quran which always be "cocok" (suitable) with scientific discoveries along the time. In 2012, Basya again published another 'controversial' work talking about Borobudur and the Prophet Solomon's artefact, Borobudur dan Peninggalan Nabi Sulaiman. Quoting luminous Quranic verses and connecting to the math and physic theories, which he 'formulated', Basya is convinced that Borobudur temple is truly connected to the history of the Prophet Solomon. Exhibiting 40 exact evidences he examined (through 33 years' research he done/he claimed), Basya confirms that Borobudur is a heritage of Queen Sheba as told by the Quran, even Indonesia itself is Sheba's country. As far as Basya is concerned, the research he conducted displays that the accuracy and precision of the Quranic information-through the basis of Islamic math-has criticized the history of Indonesian ancient world ${ }^{52}$ which is taken for granted to conclude that Hindus dan Buddhist people are Indonesian descendants. ${ }^{53}$ This Borobudur book by Basya is popular and reprinted 10 times in 2014 since it appeared. In addition, some appreciate the book as an interesting 'religious finding', but not a few who think Lajnah Pentashihan Mushaf Al-Qur'an, Balitbangdik Kemenag RI, dengan LIPI, Tafsir Ilmi: Mengenal Ayat-Ayat Sains dalam Al-Qur'an (Jakarta: Widya Cahaya, 2015).. In this series mentioned that this work is collaboration between the Ministry of Religious Affairs and The Indonesian Institute of Sciences (LIPI). No doubt, this work is the Ayatisasi model.

${ }^{50}$ Fahmi Basya, Matematika Islam: Sebuah Pendekatan Rasional untuk Yaqin (Jakarta: Penerbit Republika, 2004).

51 Indeed, Mulyadhi also wrote Sains dan Matematika Dalam Islam. See Mulyadhi Kartanegara, Sains dan Matematika dalam Islam (Jakarta: Ushul Press, 2009). Instead of ayatisasi, Mulyadhi explained the historical and philosophical aspects of mathematics and Islamic sciences in the days of Muslim philosophers.

52 Fahmi Basya, Borobudur dan Peninggalan Nabi Sulaiman (Jakarta: Zaytuna, 2012), p. vi.

${ }^{53}$ Ibid. 
that this book is ridiculous. Apparently, one who fought the book was Seno Panyadewa. He wrote Misteri Borobudur, Candi Borobudur Bukan Peninggalan Nabi Sulaiman. According to Panyadewa, the 40 evidences presented by Basya are weak and irrelevant. Through Misteri Borobudur, Panyadewa argued all of evidences and argument of Basya. Additionally, for Panyadewa, Basya's work was an insult to Indonesian ancestors. Are Hindus-Buddhists as the ancestors of Indonesia ignorant? So that the temple like Borobudur must be built by a prophet from Central Asia? ${ }^{54}$

For Armahedi Mahzar, for example, a scholar who supports the ayatisasi, conducting the tafsir ilmi, the other name of ayatisasi, is not merely a fairness but also executes the Quranic command of the importance of understanding the kauniyah verse (universe) to strengthen the qauliyyah verse (see Qur'an, Fusshilat: 53). The activity of tafsir ilmi has three benefits: to show the Quranic concept of the universe with the concepts and facts of science concordance, to show the Quran's miraculous aspects, and finally to strengthen faith in God. If there is a discrepancy between the Quranic verses and the discovery of the latest science, then the miracle of the Quran will not collapse and the Quran will not be accused of being a liar, but rather reinforce the faith that human reason, science, and interpretation are still limited to understand the deeper mystery of the Quran. ${ }^{55}$ Unlike Mahzar, Bambang Sugiharto, a Catholic theologist and professor of philosophy has a critical view. According to him, there are fundamental differences between science and religion, at least in three ways. First, the basic mind-set is different. Science rests on the autonomy of understanding ethos. Skepticism and unbelief are a scientist's nature, while religion is the opposite. The basic attitude is "to believe and surrender" to the will of other authorities, especially the authority of God. If in the scientific world, unbelief, before proven, is a virtue, then in the world of religion, belief (faith) is virtue. Second, science is relatively more open to new views as long as it makes sense and is supported by sufficient factual evidence. Religion otherwise,

54 Seno Panyadewa, Misteri Borobudur: Candi Borobudur bukan peninggalan Nabi Sulaiman (Jakarta: Dolphin, 2014), pp. 243-6.

55 Armahedi Mahzar, "Integrasi Sains dan Agama: Model dan Metodologi”, in Integrasi Ilmu dan Agama: Interpretasi dan Aksi, ed. by Zainal Abidin Bagir, Jarot Wahyudi, and Afnan Anshori (Yogyakarta: Mizan bekerja sama dengan Masyarakat Yogyakarta Untuk Ilmu dan Agama dan SUKA Press, 2005), pp. 104-6. 
it tends to be closed, conservative, and defensive to new understandings that go beyond the text. Third, if the main realm of science is empirical, the main realm of religion is the domain of the deepest mysteries of life and the meanings of experiences beyond the empirical reach. Both languages are also different. Religious language is more a mythical, and full of metaphors and rhetoric, while the language of science is a factual, straightforward, and literal. ${ }^{56}$ So for Sugiharto, the so-called "integration" between religion and science is really just an "interaction". Each has its own autonomy and uniqueness. If both are mixed, then what happens is a 'silliness', that is the empirical theology. Both will be absurd. By science theologization, the scientific weight automatically goes down. On the contrary, by empirising theology, it will be like 'philosophical empiricism', it seem to be strange and contradictory. Finally, Sugiharto concluded that 'theologization of science' actually arises because of 'politics of discourse' or by the naive religious enthusiasm..$^{57}$

\section{E. A More Academic Formulations}

Another forms of Islamic scientification which are more 'academic' is what the so-called knowledgization of Islam of Kuntowijoyo, integration of Mulyadhi Kartanegara and integration-interconnection of Amin Abdullah. Kuntowijoyo (1943-2005) is an Indonesian historian, a humanist, and is a Muslim intellectual who was educated in the Muhammadiyah traditions. Kunto, then formulated what he called 'knowledgization of Islam', 'Islamic paradigm', and 'objectification of Islam'.

According to Kuntowijoyo, Islamization of knowledge seeks to prevent Muslims from imitating of any external methods. Islamization restores knowledge to its center, i.e. tawhid (monotheism). In other words, Islamization of knowledge means restoring knowledge to tawhid (monotheism) or from context to the text. It means that there is coherence (from Latin cohaerere, which means 'to stick togother'). So that knowledge

56 Bambang Sugiharto, "Ilmu dan Agama Dalam Kurikulum Perguruan Tinggi”, in Integrasi Ilmu dan Agama: Interpretasi dan Aksi, ed. by Zainal Abidin Bagir, Jarot Wahyudi, and Afnan Anshori (Yogyakarta: Mizan bekerja sama dengan Masyarakat Yogyakarta Untuk Ilmu dan Agama dan SUKA Press, 2005), pp. 41-2.

57 Ibid., p. 46. 
can not be separated from faith. ${ }^{58}$ However, in 2004, Kunto stepped further from Islamization of knowledge. He no longer used the term anymore, but he gave a new term 'knowledgization of Islam' or 'Islam as knowledge.' For him, Islamization of knowledge is a reactive response, while knowledgization of Islam is proactive. In its process, Islamization of knowledge is now irrelevant. Text loses its context. And now, according to Kunto, knowledgization of Islam is an intellectual movement that reconnects text with context (or from text to context), so that between text and context there is correspondence. ${ }^{59}$

In conjunction with knowledgization of Islam, Kunto also formulated 'the objectification of Islam.' According to Kunto, Objectivity is the implementation of internal values into objective categories. In other words, objectivity is the concretization of abstract things to objective conditions.$^{60} \mathrm{~A}$ deed is regarded as objective if it is perceived by anyone as natural, not as a religious act. However, from the side of the subject, it is still regarded as a religious act, namely righteous deeds. ${ }^{61}$ Due to objective reality is experienced by anyone, and then Muslims are also required to act objectively. For Kunto, Islam is a religion of mercy for the universe, in the sense that Islam is revealed as a blessing to everyone regardless of religion, race, color, culture etc. Similarly, Muslims are required to be fair to anyone regardless of class and social status. Since that Islam to be perceived as a just blessing to anyone, then the objectification of Islam is important to understand. According to Kunto, Muslims are often only sensitive to abstract values such as ethics and morality, but not sensitive to concrete issues such as poverty, justice and social welfare. For Kunto, Islamic objectification means that Muslims in any profession should behave objectively: in Islamic educational institutions as well as in Islamic banks, in offices and in public spheres. ${ }^{62}$

In fact, Kunto's formulation of "Islamic objectification" is nothing new. The popular term for it may be the so-called 'good deeds,'

58 Kuntowijoyo, Islam Sebagai Ilmu: Epistemologi, Metodologi, dan Etika (Bandung: Teraju, 2004), p. 8.
59 Ibid., p. 10.
60 Ibid., p. 64.
61 Ibid., pp. 64-5.
62 Ibid., pp. 63-4. 
("amal shalib") which means that good deeds are beneficial not only to Muslims, but also to non-Muslims. But is there an objectivity of Islam that is acceptable to all sects in Islam? It was hard. Is it possible for a rich Muslim to donate his money to a Jewish church or synagogue? It was hard. The concerned may be willing to donate, but there will be very harsh criticisms from other Muslim communities. Another most actual example is the question of non-Muslim public leaders. For Islam, choosing a public leader with integrity, clean, and many achievements is actually part of what Kunto calls 'objectivity of Islam', regardless of religion and race. But when the public leader whose objectivity is undoubtedly, for example is non-Muslim, some Muslims reject it for religious reasons. Thus, the idea of Islamic objectification, in practice, turns out to depend heavily on one's Islamic understanding, whether he is an exclusivist, inclusivist, or pluralist.

The whole Kunto's formula finally culminates in what he calls 'the Islamic paradigm', a term that actually means "integration". For Kunto, nowadays existing sciences are 'the fruit' of modernism, in the sense of Westernism. Modern sciences as an independent and secular science have been separated from religion. Therefore, in this post-modern era, some Muslim scholars want a new paradigm, i.e. de-differentiation between religion and science, between revelation and ratio. Thus, the Islamic paradigm is 'the reunification' of revelation and science as integral sciences. ${ }^{63} \mathrm{In}$ turn, this science will develop into integralism against modern and postmodern secularism. Kunto believes that when Marxism became the ideological weapon of the proletariat against the bourgeoisie, then Islamic integralism is the intellectual weapon of the believers against materialism, secularism, hedonism and pragmatism. ${ }^{64}$ Obviously, there is a fury over the dominance of secular Western science in the works of Islamization of knowledge undertaken by Hidajat, Mulyadhi and Kuntowijoyo.

Compared to Hidayat and Kunto, the term "integration" is more explicit in Mulyadhi's works. Mulyadhi himself dedicated a special work for UIN Jakarta, Integrasi Ilmu Dalam Perspektif Filsafat Islam, since the campus was looking for an appropriate model of integration. Most of Mulyadhi's writings discuss the issue of Islamic epistemology vis a vis

\footnotetext{
63 Ibid., p. 61.

64 Ibid., p. 62.
} 
Western scholarship. As far as Mulyadhi is concerned, the main principle of scientific integration is monotheism (tawhìd) formula: Eailäha illa Alläh (no god but Allah). This formula is the main Islamic epistemology and becomes the very basis to unite, and even basis for integration of human knowledge. ${ }^{65}$ Theologically (as well as philosophically), supposing every single thing, but God, has genus dan spesies, then God does not have them, hence essence and existence are united in Him. This is the 'integration' within God, in which it becomes the main basic of integration for His creation. Meanwhile, the main basic integration between religious knowledge and common knowledge is God Himself as The Ultimate Truth (al-Haqq). In this respect, Allah creates the Holy Book to be the basic of religious knowledge, and the wide universe as the source of common knowledge. Both the Holy Book (Qur'aniyya) dan the universe (kawniyya) refer to the same Source, i.e. al-Haqq, the main source of every truth. ${ }^{66}$

According to Mulyadhi, knowledge integration is cannot be separated from the Islamization of science. Mulyadhi then offers the two models of Islamization dealing with science integration: Firstly, on system of science classified. Islam in its principle doctrines allow to searching various fields of science and knowledge, from physicalempirical fields to metaphysics and its ontological status in every aspects. ${ }^{67}$ As it is mentioned, the physical and the metaphysical are integrated because revealed from the One Source. Secondly, on research method. According to Mulyadhi, scientifical studies in Islam are not restricted to the physical studies such as discussed in the West, but also non-physical objects included. Therefore, if physical objects develop an experimental method (tajribi), then non-physical objects develop demonstrative-rational method (burhani) and intuitive method ('irfani). ${ }^{68}$

Mulyadhi reminds Muslims that in Islamic intellectual traditions, for example in the figures of al-Ghazali and Ibn Khaldun, there is no

65 R. Mulyadhi Kartanegara, Integrasi Ilmu dalam Perspektif Filsafat Islam (Jakarta: UIN Press, 2003), p. 13.

${ }^{66}$ Ibid., pp. $27-8$.

67 R. Mulyadhi Kartanegara, Menyibak Tirai Kejahilan: Pengantar Epistemologi Islam (Bandung: Mizan, 2003), p. 133.

${ }^{68}$ Ibid., p. 137. 
dichotomous separation between religious and non-religious knowledge. Al-Ghazali, for example, only calls sharia ('ilm syar'iyyah) and non-shariah knowledge ('ilm ghayr syar'iyyah), while Ibn Khaldun called traditional knowledge (al-ulum al-naqliyyah) and rational knowledge (al-ulum alaqliyyab). Both traditional and rational knowledge differ only in the object of study and how to obtain them. ${ }^{69}$ In the tradition of intellectual Islam, all knowledge is "illumination" that leads man to God. According to Mulyadi, this Islamic tradition distinguishes it from secular Western scholarship.

An integration-interconnection is a term formulated by Amin Abdullah in order to integrate religious studies and science in the context of State Islamic University (UIN) of Yogyakarta. This term then become a 'benchmark' of UIN Yogyakarta. Integration-interconnection is a relationship and a complex web between religious studies, science, social sciences and humanities sciences. According to Amin, to discuss on knowledge epistemology between science and religious studies is to discuss a relationship and cooperation among them. For this competence, multy-disciplinary, interconnection, and the sensitivity among such disciplines must be priorited. ${ }^{70}$

According to Amin, Islam is not the only religion that lives in the humanity midst. The interaction and encounter between Muslims and other believers is inevitable. There is a saying "no religion is in island". In today's global and complex life, religions must work together to find common solutions to the problems of mankind, ${ }^{71}$ so as interdisciplinary interaction. The science construction, whether religious studies, social science, humanities, and natural sciences can no longer stand alone. When there is a discipline that claims to stand on its own, feeling able to solve its own problems without asking for help another scientific contributions, then self-sufficiency, sooner or later, becomes a narrow-

69 Kartanegara, Menembus Batas Waketu, pp. 35-6.

${ }^{70}$ M. Amin Abdullah, "Desain Pengembangan Akademik IAIN Menuju UIN Sunan Kalijaga: Dari Pola Pendekatan Dikotomis-Atomistik ke Arah IntegratifInterdisciplinary", in Integrasi Ilmu dan Agama: Interpretasi dan Aksi, ed. by Zainal Abidin Bagir, Jarot Wahyudi, and Afnan Anshori (Yogyakarta: Mizan bekerja sama dengan Masyarakat Yogyakarta Untuk Ilmu dan Agama dan SUKA Press, 2005), p. 261.

71 M. Amin Abdullah, Islamic Studies di Perguruan Tinggi, Pendekatan IntegrasiInterkoneksi (Yogyakarta: Pustaka Pelajar, 2012), pp. 74-5. 
mindedness and scientific fanaticism that endangers itself. ${ }^{72}$ This is the integration-interconnection's importance background.

To implementing such big ideas, Amin formulates three basicprinciples of knowledge epistemology: hadārat al-nas (religion), hadàrat al-falsafah (philosophy) and hadärat al-ílm (science). These three means "trialektika" (three-alect) not dialectic (dialektika): hadärat al-nas means a tradition of text, hadärat al-ilm means a tradition of scientifical-academics, and hadarat al-falsafah means a tradition of critical-ethics. ${ }^{73}$ Dealing with Islamic higher education, the three basic-principles means iman (faith), ilmu (scince) and amal (practice). Hadarat al-nas means believe to the Holy Book, hadarat al-ilm means exploring the studies of the Holy Book, and hadarat al-falsafah is a practice in ethics and reality. ${ }^{74}$ Hence, Amin convinces that when Islamic Higher education want to develop religious studies and science altogether, then it must be remember about the three basic-princiles with three perspectives: text perspective (badārat al-nas), science and knowledge perspectives (badärat al-ílm) and philosophical perspective which is critical and transformative (hadärat al-falsafah). ${ }^{75}$

Afterwards, Amin designed what he calls 'Spider Web' ('Jaring Keilmuan Laba-laba") shows that Islamic studies can be approached by science, social sciences and humanities with broad horizon and led to be actual and contextual. ${ }^{76}$ For Amin, a Muslim will have the skill in the area of both traditional and modern life, and at the same time that can help him live in this information-globalization era. The spider-web also illustrates that a Muslim will be skilled in responding to humanitarian and religious problems in the modern and post-modern era for mastering new approaches given by the contemporary natural sciences, social science, and humanities. Above all, every step of the way is always accompanied by an objective and solid foundation of religious ethics, since the existence of the newly interpreted (hermeneutics) Quran and Sunna has always been

72 Ibid., pp. vii-viii.

73 Waryani Fajar Riyanto, Integrasi-Interkoneksi Keilmuan: Biografi Intelektual M. Amin Abdullab Person, Knowledge, and Institution (Yogyakarta: Suka Press, 2013), p. 768.

${ }^{74}$ Ibid., pp. $747-8$.

75 Ibid., pp. 771-2.

76 See Abdullah, Islamic Studies di Perguruan Tinggi, Pendekatan Integrasi-Interkoneksi, p. 107. 
the united worldview foundation in one scientific and religious breath. ${ }^{77}$

The formulation of the three figures is actually quite serious because it discusses the most basic theoretical aspects, namely ontology, epistemology and axiology. Although in Mulyadi's case, he speaks more of the history of Islamic science in "the golden age". However, the context of the formulation of Islamization of science can not be separated from the change of IAIN into UIN which has many faculties of non Islamic studies. The academic community at UIN must formulate the fundamental differences between physics, medicine or economics taught at UIN and in non-religious universities. If it is the same, then there is no distinction. In this context, Islamization of science in UIN is "strengthening the Islamic identity" or the effort to define certain Islamic identity for the university. ${ }^{78}$

\section{F. "God must be involved"? and Post-colonial Mental}

When I presented this article (with a different focus of study) at Buddhist national university, Vietnam (July 2017), a nun asked me: "When it comes to the universe, science does not talk about God, why Indonesian Muslim scholars are to talk about God as the creator of nature, when talking about science?" "What kind of science is that?" I contemplate the question quite a lot. The nature of science is on the empirical. Selfknowledge science does speak only to the empirical matters, in the sense of a tangible, quantifiable, quantitative matters and can be verified. Only arrogant and ignorant science participates in discussing metaphysical questions, which are in fact the focus of religion or philosophy. However, some of the above Muslim scholars, especially Hidajat and Mulyadhi are kind of 'demanding' that Western science also speaks of the metaphysical. If not, then with the standars of Islam as both worldly religion (dunyawr) and ukhrawi (in the metaphysical sense), Muslim scholars directly accuse Western secularists as secular and dangerous for Islamic educational institutions. So, depart from a subjective paradigm and finally reach the wrong destination. In religious studies, a person who views an object by its standars is called prescriptive, not descriptive. There is a "size"

77 Ibid., p. 106.

78 Bagir, "Expanding Science and Religion in the Pluralistic Landscape of Today's World”, p. 8. 
or a "standar" that is used as a guidance, and usually the "size" is very subjective. After all, should all those who come from the West should always be accused of being positivistic and secular? Unfortunately, both Hidajat or Mulyadhi do not discuss some aspects of Western philosophy that were influenced by Christian metaphysics and theology.

Except for Amin Abdullah, the explicit statement that the Islamization and integration project are the will against the hegemony of Western science, do in fact it contain 'political motivation'. The resistance can also be read through post-colonial studies. In this study, such statements show 'the colonized mentality' is under the colonialists. One who still feels colonized wants to fight the invaders. Ahmad Baso, in his excellent work, Islam Pasca Kolonial refers to a French psychoanalyst Jacques Lacan, who insists that colonialism is not merely a physical occupation, which means territorial, economic, and political domination, but also the subjugation of mind, body, and soul. His slogan is "the West is everywhere" to conquer and influence the East. ${ }^{79}$ Colonialism is a moral statement about the superiority of Western culture and the other cultures's inferiority. For the post-colonial mentality or whoever is traumatized by colonialism, whatever is done by colonialism must all be read in the superiority and inferiority context, and it must be resisted. The Islamic resistance to European colonialism was once phenomenal by Jamaluddin al-Afghani (1838-1897), a political activist and Islamic ideologist. In the eyes of Afghani, European colonization is not merely a physical world, but it has also penetrated the mindset and mentality of Muslims. Therefore, Afghani writes, speaks, organizes the figures and forces of Islam for one purpose: mobilization against the invaders. Afghani then devised three main points. First, it rejects the fundamentals of Western modernity. Second, it accuses those who adopt Western modernity as blind followers, traitors, and Western henchmen. Third, it calls on Muslims to return to the 'pure Islam', which is practiced by the Prophet and his successor caliphs. But according to Baso, all Afghani's efforts demand a serious consequence, namely bringing politics into religion. Political discourse is now a religious discourse. In the present language, Afghani does "Islamization of politics". Baso says, politics is

79 Ahmad Baso, Islam Pascakolonial: Perselingkuhan Agama, Kolonialisme, dan Liberalisme (Bandung: Mizan, 2005), p. 62. 
already on the head, we just have to mobilize it into an effective force to mobilize the masses by using Islam as an emotional driving force. ${ }^{80}$

Cultural identity, in some ways, is a natural condition that can not be avoided. In a state of being colonized, for example, one must fight by highlighting its identity. This is a normal. However, let's look into the context of our Indonesian tradition. Here, the view of Al-Makin (2016) can be discussed. He suggests Indonesian Muslim scholars to explore and re-read the richness of Indonesia's heritage and its legacies, from ancient texts such as Serat and Babad, the manuscripts of Nusantara Islam, the syncretic traditions: (Islam, Hinduism, Buddhist, and Chinese), and modern Indonesian thinkers such as Tan Malaka, Yamin, Soekarno, Tjokroaminoto and many others. ${ }^{81}$ Instead of always referring to Islamic traditions in the Middle East, the richness of the Indonesian tradition can be a reflection of religion-science relations. If cultural wealth is to be called "identity", then that identity is rooted in Indonesian tradition itself.

\section{G. Concluding Remarks}

I do not rebut that there are attempts to discuss seriously about religion-science relations on both ontology and epistemology aspects. Two important works such as Islam's Quantum Question: Reconciling Muslim Tradition and Modern Science ${ }^{82}$ and The Cambridge Companion To Science and Religion $^{83}$ are serious academic discussions exploring the gaps that can link or not between religion and science. Of course, the two critical works are not about to highlight any religious identity. However, what is done by Kuntowijoyo, Mulyadhi Kartanegara and Amin Abdullah for example, deserves to be appreciated as higher level academic works than just Ayatisasi. But in general, instead of demonstrating the depth of Islamic spirituality and its ethics, the phenomenon of Islamization of

80 Ibid., pp. 97-8.

81 See. Al Makin, "Are There Any Indonesian Philosophers? Dealing With a Common Question and Possible Answers", Ulumuna, Journal of Islamic Studies, vol. 20, no. 1 (2016).

82 Nidhal Guessoum, Islam's Quantum Question: Reconciling Muslim Tradition and Modern Science (London: I. B. Tauris, 2011).

83 Peter Harrison (ed.), The Cambridge Companion to Science and Religion (Cambridge: Cambridge University Press, 2010). 
knowledge/science, ayatization or theologization of science are seen-in its degree, many or few - as Islamism, or the strengthening of Islamic identity politics, or minimally: showing religious identity in an apologetic way, all of which have pragmatic, functional, economic goals, political and long-term strategic. I invite further researchers to examine these motivations. 


\section{BIBLIOGRAPHY}

Abdullah, M. Amin, "Desain Pengembangan Akademik IAIN Menuju UIN Sunan Kalijaga: Dari Pola Pendekatan Dikotomis-Atomistik ke Arah Integratif-Interdisciplinary", in Integrasi Imu dan Agama: Interpretasi dan Aksi, ed. by Zainal Abidin Bagir, Jarot Wahyudi, and Afnan Anshori, Yogyakarta: Mizan bekerja sama dengan Masyarakat Yogyakarta Untuk Ilmu dan Agama dan SUKA Press, 2005.

----, Islamic Studies di Perguruan Tinggi, Pendekatan Integrasi-Interkoneksi, Yogyakarta: Pustaka Pelajar, 2012.

Aritonang, Jan S., Sejarah Perjumpaan Kristen dan Islam di Indonesia, Jakarta: BPK Gunung Mulia, 2005.

Azra, Azyumardi, "HM Rasjidi: Pembentukan Kementerian Agama dalam Revolusi", in Menteri-Menteri Agama RI: Biografi Sosial-Politik, ed. by Azyumardi Azra and Saiful Umam, Jakarta: Badan Litbang Agama, Departemen Agama \& PPIM-IAIN, 1998.

Bagir, Zainal Abidin, "Expanding Science and Religion in the Pluralistic Landscape of Today's World", Science and Religion in a Globalizing World, Star Island, New Hampshire, 2014, https://irasconference. files.wordpress.com/2014/08/august-4-presentation-draft-irasaugust-2014-zain-bagir-2.pdf, accessed 10 May 2016.

Barbour, Ian G., When Science meets Religion: Enemies, Strangers, or Partners?, New York: Harper Collins, 2000.

Baso, Ahmad, Islam Pascakolonial: Perselingkuhan Agama, Kolonialisme, dan Liberalisme, Bandung: Mizan, 2005.

Basya, Fahmi, Matematika Islam: Sebuah Pendekatan Rasional untuk Yaqin, Jakarta: Penerbit Republika, 2004.

----, Borobudur dan Peninggalan Nabi Sulaiman, Jakarta: Zaytuna, 2012.

Bucaille, Maurice, La Bible, le Coran et la science: les Écritures saintes examinées à la lumière des connaissances modernes, Paris: Pocket, 1976.

----, What is the origin of man?: the answers of science and the Holy Scriptures, Paris: Seghers, 1984.

----, Asal-Usul Manusia Menurut Bibel, Al-Quran, Sains, trans. by Rahmani Astuti, Bandung: Mizan, 1986. 
Chalil, Moenawar, Peristiwa Israa' dan Miraadj, Djakarta: Bulan Bintang, 1960.

----, Kembali kepada al-Qur'an dan as-Sunnab: Suatu muqaddamah bagi bimpunan hadist - hadist piliban, Jakarta: Bulan Bintang, 1977.

----, Ulil Amri, Sala: Ramadhani, 1984.

Djamaluddin, Thomas, “Isra' Mi'raj: Inspirasi Mengintegrasikan Sains dalam Aqidah dan Ibadah", dakwatuna.com, 2011, http:// www.dakwatuna.com/2011/06/27/12964/isra-miraj-inspirasimengintegrasikan-sains-dalam-aqidah-dan-ibadah/.

Guessoum, Nidhal, Islam's Quantum Question: Reconciling Muslim Tradition and Modern Science, London: I. B. Tauris, 2011.

Hamka, Tafsir al-Az̧ar, vol. 1, Jakarta: Pustaka Panjimas, 1983.

Harrison, Peter (ed.), The Cambridge Companion to Science and Religion, Cambridge: Cambridge University Press, 2010.

Jumin, Hasan Basri, Sains dan Teknologi dalam Islam tinjanan Genetis dan Ekologis, Jakarta: PT RajaGrafindo Persada, 2012.

Kartanegara, Mulyadhi, Sains dan Matematika dalam Islam, Jakarta: Ushul Press, 2009.

Kartanegara, R. Mulyadhi, Menembus Batas Waktu: Panorama Filsafat Islam, Bandung: Mizan, 2002.

----, Integrasi Ilmu dalam Perspektif Filsafat Islam, Jakarta: UIN Press, 2003.

----, Menyibak Tirai Kejabilan: Pengantar Epistemologi Islam, Bandung: Mizan, 2003.

Kuntowijoyo, Islam Sebagai Ilmu: Epistemologi, Metodologi dan Etika, Bandung: Teraju, 2004.

Lajnah Pentashihan Mushaf Al-Qur'an, Balitbangdik Kemenag RI, dengan LIPI, Tafsir Ilmi: Mengenal Ayat-Ayat Sains dalam Al-Qur'an, Jakarta: Widya Cahaya, 2015.

Lajnah Pentashihan Mushaf al-Qur'an Kementerian Agama, Penciptaan Jagat Raya dalam Perspektif Al-Qur'an dan Sains, Jakarta: Lajnah Pentashihan Musahaf al-Qur'an, Badan Litbang \& Diklat, Kementerian Agama RI, 2012.

Madinier, Remy, Partai Masjumi: Antara Godaan Demokrasi \& Islam Integral, 
Bandung: Noura Book Publising, 2013.

Madjid, Nurcholish, "Metodologi dan Orientasi Studi Islam Masa Depan”, Khazanah, Jounal of Islamic Studies, vol. 1, no. 1, 2002.

Magdalena, Federico V., "Islam and the Politics of Identity", Center for Philippine Studies, http://www.hawaii.edu/cps/identity.html, accessed 6 Jun 2016.

Mahzar, Armahedi, "Integrasi Sains dan Agama: Model dan Metodologi", in Integrasi Ilmu dan Agama: Interpretasi dan Aksi, ed. by Zainal Abidin Bagir, Jarot Wahyudi, and Afnan Anshori, Yogyakarta: Mizan bekerja sama dengan Masyarakat Yogyakarta Untuk Ilmu dan Agama dan SUKA Press, 2005.

Makin, Al, "Are There Any Indonesian Philosophers? Dealing With a Common Question and Possible Answers", Ulumuna, Journal of Islamic Studies, vol. 20, no. 1, 2016.

Nataatmadja, Hidajat, Karsa Menegakkan Jiwa Agama dalam Dunia Ilmiab: Versi baru Ibya Ulumuddin, Bandung: IQRA, 1982.

Noer, Deliar, Membincangkan Tokoh-Tokoh Bangsa, Bandung: Mizan, 2001.

Panyadewa, Seno, Misteri Borobudur: Candi Borobudur bukan peninggalan Nabi Sulaiman, Jakarta: Dolphin, 2014.

Purwanto, Agus, Nalar Ayat-Ayat Semesta: Menjadikan al-Qur'an Sebagai Basis Konstruksi Ilmu Pengetahuan, Bandung: Mizan, 2015.

Rakhmat, Ioanes, Beragama dalam Era Sains Modern, Jakarta: Pustaka Surya Daun, 2013.

Rasjidi, H.M., Koreksi terhadap Drs. Nurcholis Madjid tentang sekularisasi, Jakarta: Bulan Bintang, 1972.

----, Koreksi terhadap Dr. Harun Nasution tentang "Islam ditinjau dari berbagai aspeknya”, Jakarta: Bulan Bintang, 1977.

----, "Pengantar", in Bibel, Quran, dan Sains Modern, trans. by H.M. Rasyidi, Jakarta: Bulan Bintang, 1978.

Riyanto, Waryani Fajar, Integrasi-Interkoneksi Keilmuan: Biografi Intelektual M. Amin Abdullah Person, Knowledge, and Institution, Yogyakarta: Suka Press, 2013.

Roberts, Jon H., "Religious Reactions to Darwin", in The Cambridge 
Companion to Science and Religion, ed. by Peter Harrison, Cambridge: Cambridge University Press, 2010.

Ropi, Ismatu, Fragile Relation: Muslims and Christians in Modern Indonesia, Jakarta: Logos Wacana Ilmu, 2000.

----, Religion and Regulation in Indonesia, Singapore: Palgrave Macmillan, 2017.

Shihab, M. Quraish, Membumikan Al-Quran, Bandung: Mizan, 2003.

Subandi, M. and Hany Hanita Humanisa, Science and Technology Some Cases in Islamic Perspective, Bandung: Remaja Rosdakarya, 2011.

Sudarmojo, Ir Agus Haryo, Menyibak Rahasia Sains Bumi Dalam Al-quran, Jakarta: Mizania, 2008.

Sugiharto, Bambang, "Ilmu dan Agama Dalam Kurikulum Perguruan Tinggi", in Integrasi Ilmu dan Agama: Interpretasi dan Aksi, ed. by Zainal Abidin Bagir, Jarot Wahyudi, and Afnan Anshori, Yogyakarta: Mizan bekerja sama dengan Masyarakat Yogyakarta Untuk Ilmu dan Agama dan SUKA Press, 2005.

Syarif, Edwin, "Islamisasi Ilmu di UIN Syarif Hidayatullah Jakarta", Ph.D. Dissertation, Jakarta: UIN Syarif Hidayatullah, 2011.

Tibi, Bassam, Islamism and Islam, New Haven: Yale University Press, 2012. Wahib, Ahmad, Pergolakan Pemikiran Islam: Catatan Harian Abmad Wabib, ed. by Djohan Effendi and Ismed Natsir, Jakarta: Lembaga Penelitian, Pendidikan dan Penerangan Ekonomi dan Sosial, 2003.

Yahya, Kadirun, Isra Miraj Rasulullah Saw: Ditinjau dari Sudut Ilmu FisikaEksakta, Medan: Lembaga Ilmiah Metafisika Tasauf Islam, 1985.

Yusuf, Ali Anwar, Islam dan Sains Modern: Sentuhan Islam terbadap berbagai disiplin ilmu, Bandung: Pustaka Setia, 2006. 